\title{
JURIDICAL CRIPPLES: PLURALITY OPINIONS IN THE SUPREIIE COURT
}

\author{
JOHN F. DAVIS* \& WILLIAM L. REYNOLDS**
}

\begin{abstract}
The Supreme Court's growing tendency to resort to "plurality opinions" has produced substantial uncertainty among the bench and bar as to the precedential value of cases so decided. In this Article, Professors Davis and Reynolds demonstrate that the ambivalent nature of the plurality opinion adversely affects the Court's extra-legal leadership functions and its own internal process of developing the law, as well as the precedential value of the increasing number of decisions announced in that format. After examining various factors which tend to generate plurality decisions, the authors suggest that the refinement of two existing methods of decision-formulation could possibly alleviate the problems created by the plurality opinion.
\end{abstract}

In recent Terms the Supreme Court has handed down an increasing number of decisions introduced by this familiar rubric: "Mr. Justice $A$ announced the judgment of the Court and an opinion in which Mr. Justice B, Mr. Justice C and Mr. Justice D join." This description of the action taken has been utilized when the opinion announced has not been acceptable to a majority of the justices sitting in a case, but where a judgment disposing of the case can be supported by combining two or more separate opinions. ${ }^{1}$ It is custoinary to refer to such opin-

* A.B. 1928, Bates College; LL.B. 1932, Harvard University; Member of the District of Columbia and New York Bars; Visiting Professor of Law, University of Maryland School of Law, 1973-74.

** A.B. 1967, Dartmouth College; J.D. 1970, Harvard University; Assistant Professor of Law, Umversity of Maryland School of Law.

1. E.g., Frontiero v. Richardson, 411 U.S. 677 (1973). Although cases decided by "an equally divided Court" technically fall within this definition, the practice of the Court in such cases is markedly different from that in the cases which we shall discuss. In the former category, no opinion of any individual justice is published, the only announcement being that "the judgment is affirmed by an equally divided Court." If the full Court did not participate in the case, the names of the justices who recused thenselves are noted. E.g., United States v. First National Bancorporation, Inc., 410 U.S. 577 (1973). However, in In re Isserman, 345 U.S. 286 (1953), the Court departed from this practice by announcing that there was an equally divided Court and then publishing two opinions, each joined in by four justices. Perhaps the departure froin the traditional practice is attributable to the fact that the case involved a show cause order in the Suprenie Court with respect to the revocation of Mr. Isserman's right to practice there; there was, therefore, no judgment below to be affirmed. Decisions by an equally divided Court clearly do not constitute precedent. United States v. Pink, 315 U.S. 203, 216 (1942).

A somewhat different practice is followed when a majority of the Court agrees on a summary joint expression of views with the members of the coalition also express- 
ions as "plurality" or "no-clear-majority" opinions.

Though the formulation of the announcement is traditional, actual resort to the device had been so infrequent throughout the history of the Court that, until the later years of the Warren Court, one could justifiably dismiss it as an insignificant aberration. A study made by the University of Chicago Law Review in $1956^{2}$ disclosed that from the early 1800's, when the pohicy of handing down seriatim opinions in the English style was discarded by Chief Justice Marshall, ${ }^{3}$ until the date of the study, there had been only 45 cases in which the Court was unable to muster a clear majority. ${ }^{4}$ Of those 45 cases, 35 were dated after 1900 and 27 of those 35 were handed down between 1938 and 1956.5 In the seventeen-year period since the 1955 Term, however, there have been no less than 61 plurality-opinion cases, 26 of which occurred in the last three Terms, and 15 of which were handed down in the 1970 Term alone. ${ }^{\circ}$ Given this distinct increase in the

ing their views separately. E.g., New York Times Co. v. United States, 403 U.S. 713 (1971). This technique utilizes the "per curiam" opinion and is discussed more extensively in the text accompanying notes 122-35 infra. Because there is a common expression by the majority, such a decision cannot be described as a "plurality" decision.

For an analytical study of plurality decisions see Comnent, Supreme Court NoClear-Majority Decisions: A Study in Stare Decisis, 24 U. ChI. L. Rev. 99 (1956). See also Comment, A Suggestion for the Prevention of No-Clear-Majority Judicial Decisions, 46 TEX. L. REv. 370 (1968).

HEREINAFTER THE FOLLOWING CITATION WILL BE USED IN THIS ARTICLE:

Comment, Supreme Court No-Clear-Majority Decisions: A Study in Stare Decisis, 24 U. ChI. L. REv. 99 (1956) [hereinafter cited as Chicago Comment].

2. Chicago Comment.

3. ZoBell, Division of Opinion in the Supreme Court: A History of Supreme Court Disintegration, 44 CORNELL L.Q. 186, 192-93 (1959).

4. Chicago Comment 99 n.4.

5. Id. at 99-100.

6. The fifteen plurahty opinions handed down in the 1970 term were the following: Dutton v. Evans, 400 U.S. 74 (1970); Oregon v. Mitchell, 400 U.S. 112 (1970); United States v. Jorn, 400 U.S. 470 (1971); Baird v. State Bar of Ariz., 401 U.S. 1 (1971); In re Stolar, 401 U.S. 23 (1971); Williams v. United States, 401 U.S. 646 (1971); Mackey v. United States, 401 U.S. 667 (1971); United States v. White, 401 U.S. 745 (1971); United States v. Thirty-Seven Photographs, 402 U.S. 363 (1971); California v. Byers, 402 U.S. 424 (1971); Rosenbloom v. Metromedia, 403 U.S. 29 (1971); Whitcomb v. Chavis, 403 U.S. 124 (1971); McKeiver v. Pennsylvania, 403 U.S. 528 (1971); United States v. Harris, 403 U.S. 573 (1971); and Tilton v. Richardson, 403 U.S. 672 (1971).

The 1971 term produced seven such opinions, Adams v. Illinois, 405 U.S. 278 (1972); Loper v. Beto, 405 U.S. 473 (1972); Apodaca v. Oregon, 406 U.S. 404 (1972); United States v. Midwest Video Corp., 406 U.S. 649 (1972); Kirby v. Illinois, 406 U.S. 682 (1972); First National City Bank v. Banco Nacional de Cuba, 406 U.S. 
Court's resort to the plurality opinion, the nature and meaning of this form of decision should become of increasing significance to the bench and bar.

This Article will first explore the effects of plurality decisions on the Court's ability to influence the course of general social change, on its own development of constitutional law, and on the efforts of lower courts to conform their decisions to those of the High Court. The Article will then examine the reasons underlying the recent increase in plurality decisions, and suggest some methods which the Court might adopt to ameliorate the detrimental effects which are often the by-product of such decisions.

\section{Function AND EFfect of Supreme Court Decisions}

\section{Opinions and Judgments}

The importance of the failure of the Court to muster a clear majority behind an opinion depends in part on the Supreme Court's role in society. Traditionally, of course, the Court's primary function has been that of a tribunal whose institutional pronouncements guide and bind the process of adjudication both in the state courts and in the lower federal courts. ${ }^{7}$ In that context a plurality opinion is not, strictly speaking, an opinion of the Court as an institution; it represents nothing more than the views of the individual justices who join in the opinion. ${ }^{8}$ A plurality opinion does not, therefore, essentially differ in character from either a concurring opinion or a dissenting opinion. Those joining in a plurality opinion may speak with the authority accorded wise

759 (1972); Peters v. Kiff, 407 U.S. 493 (1972) and the 1972 term just concluded produced four, Lemon v. Kurtzman, 411 U.S. 192 (1973); Frontiero v. Richardsou, 411 U.S. 677 (1973); Atchison T. \& S.F. Ry. v. Wichita Bd. of Trade, 412 U.S. 800 (1973); Gosa v. Mayden, 413 U.S. 665 (1973). Picking prior Terms at random, this contrasts with only two such opinions occurring in each of the 1952 (Terry v. Adams, 345 U.S. 461 (1953); Burns v. Wilson, 346 U.S. 137 (1953)) and 1962 (Kennedy v. Mendoza-Martimez, 372 U.S. 144 (1963) and Ker v. California, 374 U.S. 23 (1963)) Terms.

7. Cf. Monaghan, Constitutional Adjudication: The Who and When, 82 YAL L.J. 1363, 1365-71 (1973).

8. The Court quite clearly makes this distinction in pronouncing its judgments: a majority opimion is announced as "the opinion of the Court;" a plurality opinion, on the other hand, is announced only as "an opinion" of its author aud those concurring therein. See text accompanying note 1 supra. The pointed references which members of the Court make to the fact that an opinion is that of a plurality only further reenforces the view that such opinions hold an inferior rank in the juridical hierarchy. See, e.g., the cominents of Chief Justice Burger in Miller v. California, 413 U.S. 15, 21-22, 26 (1973), and Loper v. Beto, 405 U.S. 473, $489-90$ (1972). 
men, but their voices do not carry the authority of the Supreme Court as an institution. This difference in weight is important in several respects. First, the fact that an opinion is supported by only a plurality of the Court may compromise its professional and public acceptance. Second, within the Court itself, a no-clear-majority decision will carry less precedential weight. Third, a plurality opinion often fails to give definitive guidance as to the state of the law to lower courts-both state and federal - as well as to the legislative, administrative, and executive agencies charged with implementing the standards so ambivalently articulated by the Court. Thus, there results a collective confusion as to what has been held by the Court in the plurahty case. For example, in the past decade, the Supreme Court, the lower courts, and sometimes the legislatures, have been forced to wrestle at great length with the problems raised-but not settled-by the plurality opinions in the retroactivity ${ }^{9}$ and obscenity ${ }^{10}$ cases. Those cases may have done more to confuse the current state of the law than to clarify it.

In analyzing these problems, it is essential to distinguish between the function of a court's judgments and that of the opinions supporting them. The function of a judgment, traditionally, lias been to decide disputes between litigants. This is not the primary task of the Supreme Court, though it is constitutionally required that there exist sucli a dispute for the Court to assert jurisdiction in the first instance. ${ }^{11}$ The particular case or controversy before the Court is the vehicle utilized by it to establish principles of law which will not only decide the dispute between the parties at bar but which will also be applicable in a broad range of similar disputes. Occasionally, however, it is the settlement of the particular dispute at bar which is important, not the particular line of analysis used in reaching the conclusion. Thus, the composite decision reached in Glidden Co. v. Zdanok, ${ }^{12}$ holding that the Courts of Claims and of Customs and Patent Appeals are "Constitutional Courts" is what is important in that case; the fact that there was no majority opinion supporting that result has not impaired the usefuhress of the decision. When Glidden is cited for its conclusion that the Court of Claims is a "Constitutional Court," it is the outcome of the case that is relied on, and the opinion writer does not find it necessary to note that the case was decided by a plurality opinion. ${ }^{13}$

9. See notes 30-43 infra and accompanying text.

10. See notes $22-27$ and 50-55 infra and accompanying text.

11. U.S. ConST. art. III, § 2; Flast v. Cohen, 392 U.S. 83, 94 (1968).

12. 370 U.S. 530 (1962).

13. See, e.g., O'Connor v. Heritage, 306 F.2d 458 (5th Cir. 1962). This past term the Supreme Court referred to Glidden three times in its opinion in Palmore v. United 
In many instances, however, a decision of the Supreme Court is more important for the reasons articulated in support of the conclusion than for the immediate impact of the judgment itself. For example, in Gideon v. Wainwright, ${ }^{14}$ the fact that Mr. Gideon's conviction was vacated and the case remanded for further proceedings which eventually resulted in his acquittal was of real importance to Mr. Gideon only; while the basis for that action, that the sixth amendment required the appointment of a lawyer in every state felony criminal case wherein the accused could not afford to retain his own counsel, required vast changes in criminal procedure in Florida and throughout the United States. The impact of Gideon would have been quite different had the sixth amendment justification been adopted not by a majority of the Court but by only three or four justices, with the others concurring in the judgment on the ground that they believed special circumstances required the appointment of a lawyer for the trial of the particular case. ${ }^{15}$ It is this type of situation in which the effects of plurality opinions are most deeply felt.

\section{Effect on the Leadership Functions of the Court}

Frequently the opinions of the Supreme Court lave an influence beyond the sphere of the purely "legal" world by placing the imprimatur of respectable moral leadership upon controversial social or economic reforms. The outstanding case in recent years which dramatically illustrates the power of the Supreme Court to so speak for the conscience of the nation is Brown v. Board of Education. ${ }^{16}$ Chief Justice Warren's disclosure of the length of time between arguments and the taking of a vote on the case-from October to the following February-in the

States, 411 U.S. 389 (1973). First, it cited the general holding in Glidden without quoting from any of the separate opinions. Id. at 403 n.10. Here it made no reference to the fact that a plurality opinion was involved. However, in its footnote $13, i d$. at 405 , the Court referred to the language of the plurality opinion and noted that the opinion was that of the justices joining in it rather than that of the Court. Somewhat inconsistently it mcluded another quotation from the plurality opinion without identifying it as such. Id. at 404.

14. 372 U.S. 335 (1963).

15. Prior to the decision in Gideon at least four members of the Court had indicated that they believed Betts v. Brady, 316 U.S. 455 (which held that the fonrteenth amendment did not invariably require the right to counsel in non-capital state criminal cases), should be overruled. See Carnley v. Cochran, 369 U.S. 506 (1962); McNeal v. Culver, 365 U.S. 109 (1961). Thus, a mere four-man plurality opinion supporting the Gideon deeision would have done nothing to alter the stance of the Court on the broader issue of the right to counsel in state criminal cases in general.

16. 347 U.S. 483 (1954). 
Court's conference, ${ }^{17}$ gives a hint of how carefully the Court proceeded in an attempt to arrive at a common ground for decision. ${ }^{18}$ The unanimous opinion which resulted may not have been the finest possible analysis of the issues involved, or even the best justification of the result, but it was, presumably, the highest common denommator on which all the members of the Court could agree. Suppose that instead of that unanimous opinion, the Court had been able to deliver a more detailed and thorough exposition of the probleins and their solutions, such as that pronounced in Swann v. Charlotte-Mecklenburg Board of Education $^{19}$ or Keyes v. Denver School District No. $1 .^{20}$ Would that additional analysis, and a farsighted effort to undertake such sweeping solutions as "busing" and "neighborhood schools," have led to a speedier or easier iniplementation of the decision? Or would that additional exegesis have lost the support of one or more conservative members of the Court, creating a nucleus of hope around which even greater opposition to the decision could have coalesced? If the Court had further split into a majority divided against itself, if the justices had spoken as nine individuals rather than as "the Supreme Court," the moral authority of Brown would perhaps have been too diluted to have led to even the gradual social changes which it in fact inspired.

Contrast the strong leadership given by the consistently unanimous decisions in the integration cases ${ }^{21}$ with the sharp division which characterized the Court's efforts to establish standards for obscenity in Fanny Hill ${ }^{22}$ and succeeding cases. ${ }^{23}$ While a battle cry to protect smut perhaps lacks the firm moral tone of the integration cases, it is not without higher appeal if couched in free speech terms, as was so aptly

17. The Chief Justice's remarks were made in a televised interview at Brandeis University broadcast over the educational television network in late 1972.

18. The time was well spent, for the unanimity of the Court on school integration cases lasted nearly two decades and through sixteen justices until the decisions in Wright v. Council of the City of Emporia, 407 U.S. 451 (1972), and United States v. Scotland Neck City Bd. of Educ., 407 U.S. 484 (1972).

19. 402 U.S. 1 (1971).

20. 413 U.S. 189 (1973).

21. E.g., Swann v. Charlotte-Mecklenburg Bd. of Educ., 402 U.S. 1 (1971); Raney v. Board of Educ., 391 U.S. 443 (1968); Green v. County School Bd., 391 U.S. 430 (1968); Griffin v. Prince Edward County School Bd., 377 U.S. 218 (1964); Brown v. Board of Educ., 347 U.S. 483 (1954).

22. A Book Named "John Cleland's Memoirs of a Woman of Pleasure" v. Attorney General, 383 U.S. 413 (1966).

23. E.g., United States v. Thirty-Seven Photographs, 402 U.S. 363 (1971); Ginsberg v. New York, 390 U.S. 629 (1968); Redrup v. New York, 386 U.S. 767 (1967); Ginzburg v. United States, 383 U.S. 463 (1966) (four dissents). 
demonstrated by Justice Black. ${ }^{24}$ Because the free speech issues are easily lost in the highly emotional debate over pornography, it is essential that those who would protect them speak as clearly as possible if public support for that effort is to be obtained. The Warren Court, lowever, was consistently unable to find an enduring rationale for its obscenity decisions which could attract the support of a majority. ${ }^{25}$ Each obscenity judgment was rendered on the basis of the individual case before the Court, thus leaving no authoritative opinion which the lower courts could look to for a comprehensive statenient. It was not until the closing days of the 1972 Term, when Chief Justice Burger was able to muster a majority in support of his "conteniporary community standards" test in Miller v. California ${ }^{26}$ that an authoritative pronouncement of the Court's position fimally became available. In the meantime, the nation could only uneasily perceive a growing moral permissiveness; none of the separate opinions which spoke on either side of the issue spoke with sufficient clarity and force to act as a countervailing focus. Perlaps no opinion, even if backed by a unanimous ing).

24. See Ginzburg v. United States, 383 U.S. 463, 481-82 (1966) (Black, J., dissent-

25. But see Roth v. United States, 354 U.S. 476 (1957), where the Court was at least able to unuster a majority in support of the proposition that obscenity is not constitutionally protected speech. Id. at 484-85. But as the Chief Justice remarked in Miller v. California, 413 U.S. 15 (1973):

Apart from the initial formulation in the Roth case, no majority of the Court has at any given time been able to agree on a standard to determine what constitutes obscene, pornographic material subject to regulation under the States' poice power. Id. at 22 .

26. 413 U.S. 15 (1973). The Miller majority rejected the Fanny Hill test of whether the material in question was "utterly without redeeming social value" in favor of a three-pronged test of:

(a) whether "the average person, applying contemporary community standards" would find that the work, taken as a whole, appeals to the prurient interest; (b) whether the work depicts or describes, in a patently offensive way, sexual conduct specifically defined by the applicable state law; and (c) whether the work, taken as a whole, lacks serious biterary, artistic, political, or scientific value. Id. at 24 .

See note 128 infra and accompanying text.

Four justices are still unhappy over the most recent formulation, id. at 37 (Douglas, J., dissenting) and 47 (Brennan, J., dissenting (joined by Stewart and Marshall, J.J.)), but, since it represents a majority position, the lower courts can be left the task of applying its standards. But cf. Trinkler v. Alabama, 94 S. Ct. 265 (Oct. 23, 1973) (mem.) (Douglas, J., dissenting).

However, since the Court has granted review in two recent obscerity cases, Jenkins v. Georgia, review granted, 42 U.S.L.W. 3347 (U.S. Dec. 12, 1973) (No. 73-557) and Hamling v. United States, review granted, 42 U.S.L.W. 3400 (U.S. Jan. 15, 1974) (No. 73-507), perhaps the last word is yet to be heard in this area. In the former case, the Court will be called upon to refine Miller by deciding whether it is constitutionally permissible to employ "local," as opposed to statewide, contemporary community standards in evaluating prurient interest appeal and patent offensiveness, 42 U.S.L.W. at 3347. 
Court, could have done so in an area so marked by controversy; ${ }^{27}$ it seems certain, however, that enthusiastic acceptance of the results in the pre-Miller cases was unlikely to be nurtured by the separate voices of a divided Court.

\section{Confusion within the Court}

A further aspect in which the use of plurality opinions detracts froin the Court's optimum performance of its proper role is in failing to provide a foundation which can give stability to the Court's own development of constitutional law. Justices who have concurred in a plurality opinion exercise a greater freedom to change their positions in later cases than they would enjoy had the opinion been an opinion "of the Court."28 Similarly, new members who join the Court after the pronouncement of a plurality opinion are free to diverge from the plurality view without considering the serious consequences of overruling a precedent firmly established by a majority of the Court. ${ }^{29}$ As a result, the law develops not in an orderly process of logical progression, but in a confused ebb and flow of divergent concepts. One case cannot build upon another because the uncertain status of prior decisions provides no foundation for further departures.

The Court's utter confusion in determining whether its new constitutional adjudications in the field of criminal procedure should be

27. Indeed, since by its very nature the concept of "obscenity" seems to evoke sharply differing interpretations in the minds of many people, the Court's pre-Miller failure to achieve anything approaching a consensus on the subject may have been an accurate reflection of the broad divisions in American society as to what constitutes "obscene" inatter. Thus, the Miller majority's decision to allow at least part of the "obscenity" question to be determined by "contemporary community standards" may be viewed as the Court's authoritative concession that comprehensivc judicial standards are simply unobtainable in this area.

28. In Desist v. United States, 394 U.S. 244, 258 (1969), Mr. Justice Harlan in dissent said:

I have in the past joined in some of the opinions which have, in so short a time, generated so many incompatible rules and inconsistent principles. I did-so because I thought it important to limit the impact of constitutional decisions which seem to ane profoundly unsound in principle. I can no longer, however, remain content with the doctrinal confusion that has characterized our efforts to apply the basic Linkletter principle. "Retroactivity" must be rethought.

See also Justice Marshall's dissent in Michigan v. Payne, 412 U.S. 47, 59 (1973).

29. In Miller v. Califorina, 413 U.S. 15 (1973), all four of the new members of the Court appointed since 1967 (joined by Justice White) combined to establish the new formula which replaced the plurality opinions' approach in the obscenity area. $C f$. the dissenting opinion of Justice Blackmun in TelePrompter Corp. v. CBS, 43 U.S.I.W. 4323, 4331 (Mar. 4, 1974). 
given retroactive application or be applied prospectively only, and, if the latter, on the basis of what cutoff date, illustrates this weakness of the plurality opinion. Traditionally, judicial rulings had been considered to have retroactive application, even if they announced new law. ${ }^{30}$ This is in contrast with legislation, which is ordinarily prospective in application. However, in Linkletter $v$. Walker, ${ }^{31}$ decided in 1965, the Court broke new ground by holding that its decision in Mapp v. Ohio, ${ }^{32}$ which had applied to the states the exclusionary rule for evidence obtained in an illegal search, should not be applied to cases which had achieved finality prior to Mapp. The Court decided Linkletter by a substantial majority of seven to two. In all the confusion which has followed that ruling there has been no real challenge to the basic theory that, under proper circumstances, the Court may apply its new rulings prospectively, yet the question of what constitutes those proper circumstances has divided the Court so thoroughly that fourteen of the fifteen justices who have been on the Court since Linkletter have written opinions attempting to find a rationale acceptable to a majority of the Court. ${ }^{33}$ Except for several per curiam opinions, which found a common ground for retroactivity in cases in which the contested procedural rule was deemed central to the process of determining guilt or innocence, ${ }^{34}$ all twenty-four post-Mapp retroactivity cases were decided by plurality votes until 1973.

In the $1972 \mathrm{Term}$, it appeared as though the Court had formulated a retroactivity rationale which could be supported by a majority when Robinson v. Neil ${ }^{35}$ was decided without dissent, and Michigan $v$. Payne $^{36}$ was decided by a six-to-three vote. Both of those cases may be read to support the proposition that a distinction is to be drawn between prophylactic procedural rules, such as the "exclusionary rule of Mapp," and more basic constitutional imterpretations, such as those dealing with the substantive content of the cruel and unusual punish-

30. In Kuhn v. Fairmont Coal Co., 215 U.S. 349, 372 (1910), Justice Holmes, dissenting, stated: "I know of no authority in this court to say that in general state decisions shall make law only for the future. Judicial decisions have had retrospective operation for near a thousand years."

31. 381 U.S. 618 (1965).

32. 367 U.S. 643 (1961).

33. Only Justice Goldberg, who left the Court shortly after the decision in Linkletter, failed to write on the subject.

34. Ivan V. v. New York, 407 U.S. 203 (1972); Berger v. California, 393 U.S. 314 (1969); McConnell v. Rhay, 393 U.S. 2 (1968); Arsenault v. Massachusetts, 393 U.S. 5 (1968).

35. 409 U.S. 505 (1973).

36. 412 U.S. 47 (1973). 
ment clause or the double jeopardy clause, in determining whether application is to be retroactive. ${ }^{37}$ Retroactive application would normally be indicated in the latter context, but not in the case of prophylactic procedural rules, aimed at deterring conduct not "affect[ing] the basic fairness of the earlier trial." 38 On the last day of the 1972 Term, however, the Court announced its judgment in Gosa v. Mayden. ${ }^{30}$

Gosa involved the retroactivity of $O^{\prime}$ Callahan $v$. Parker, ${ }^{40}$ which had announced a severe limitation on the jurisdiction of courts-martial to try non-service-connected offenses. Characterizing the $O^{\prime} C a l l a-$ han rule as one concerning the appropriate exercise of jurisdiction and representing an abrupt break with the past, Justice Blackmun wrote a plurality opinion with which the Chief Justice and Justices White and Powell concurred, holding that $O^{\prime}$ Callahan was not retroactive. Justice Rehnquist concurred in the result on the ground that $O^{\prime}$ Callahan was wrongly decided and should be overruled, ${ }^{41}$ but he stated his view that if $O^{\prime}$ Callahan were to be followed then it would deserve retroactive application. It would seem that since O'Callahan was not being overruled, Justice Rehnquist might have felt himself required to dissent from the Blackmun result rather than support it, but he may have determined that demial of retroactivity amounted to a pro tanto overruling. Justices Marshall, Brennan, and Stewart dissented in Gosa on the ground that retroactive effect should be given $O^{\prime}$ Callahan, ${ }^{42}$ and Justice Douglas went off on a frolic of his own on the issue of whether the petitioner lad not waived his right to object to the jurisdiction of the court-martial by not raising it in a timely fashion. ${ }^{43}$ It could arguably be asserted that a combination of the plurality opinion and the opinion of Justice Rehnquist results in five justices, a majority, holding that O'Callahan should not be applicable to prior courts-martial; but such a contrived majority hardly establishes the kind of constitutional precedent that is likely to survive changes in the Court's personnel. While the present justices continue to sit it inust be assumed that they would decide other court-martial cases consistently with Gosa, but Gosa falls short of settling the law on the issue.

37. 409 U.S. at 508-10; 412 U.S. at 51-54.

38. Robinson v. Neil, 409 U.S. 505, 509 (1973).

39. 413 U.S. 665 (1973).

40. 395 U.S. 258 (1969).

41. 413 U.S. at 692 . Similarly, Chief Justice Burger had concurred in the result in Adams v. Illinois, 405 U.S. 278 (1972), a case denying retroactivity to the prior decision in Coleman v. Alabama, 399 U.S. 1 (1970), on the ground that he disagreed with the decision in Coleman. 405 U.S. at 285.

42. 413 U.S. at 693.

43. Id. at 686 . 
Thus after eight years and more than two dozen cases, the Court has been unable to arrive at a common ground on the retroactivity issue. The plurality opinions have decided only the cases before the Court and, in a limited way, have made the apphication of the retroactivity doctrines predictable only when the facts are similar to those in the decided cases and while the present justices remain on the Court. But they have failed to articulate a basis for decision whicl can be applied comprehensively or which can be expected to survive.

Other examples of confusion in the development of new concepts in constitutional law can be found in the Court's initial efforts to wrestle with the problems of reapportionment and obscemity. In the reapportionment field, for exainple, confusion began with Colegrove $v$. Green. ${ }^{44}$ Colegrove rejected the petitioner's constitutional challenge to Illinois' congressional districting scheme: three of the seven sitting Justices thought the issue non-justiciable, ${ }^{45}$ three were convinced to the contrary, ${ }^{46}$ and one, Justice Rutledge, rested his concurring opinion on the discretion given an equity court to decline to act in certain circumstances. ${ }^{47}$ Colegrove thus decided only that the particular plea for rehef in that case should be demied; the Court reached no decision on the general question of whether or not challenges to reapportionment schemes present a justiciable issue. Yet Colegrove, within two years of its announcement, was cited by a majority of the Supreme Court as if it had been a decision on the merits. ${ }^{48}$ Quite obviously, the Colegrove Court, as an institution, failed to make any contribution to the settlement of the precise constitutional issues presented by that case. As a result, the reapportionment question was left suspended for a full sixteen years before the Supreme Court was able to resolve the justiciability issue in Baker v. Carr..$^{40}$

A fimal example of this confusion in the Court's own decisionmaking process is again provided by the obscenity cases. The individual members of the Court have exhibited a great diversity of opinion on the subject-froin Justices Black and Douglas, who would have ex-

44. 328 U.S. 549 (1946). See generally Neal, Baker v. Carr: Politics in Search of Law, 1962 Sup. CT. Rev. 252, 255-57; Chicago Comment 120-23.

45. 328 U.S. at 552 (opinion of Justice Frankfurter, concurred in by Justices Reed and Burton).

46. Id. at 570-72 (opinion of Justice Black, concurred in by Justices Douglas and Murphy).

47. Id. at 565 .

48. MacDougall v. Green, 335 U.S. 281, 284 (1948) (per curiam). There were also three dissenters and one concurrer in MacDougall: each had participated in Colegrove; each cited Colegrove only for his own earlier opinion in that case.

49. 369 U.S. 186 (1962). 
tended full first amendment protection to obscenity; ${ }^{50}$ through Justice Brennan (and others) who, in general, would have banned "hard core pornography," sales to the young, and "pandering;"51 to Justice Harlan, who was willing to give the states a great deal of leeway in the matter and the federal government hittle. ${ }^{52}$ Between 1966 and 1973, for instance, although the justices spoke often on the subject, the Court, as a Court, spoke only through judgments the sole nuessage of which was that government would henceforth be allowed less leeway in regulating the reading habits and visual amusements of the citizenry. ${ }^{53}$ The multiplicity of viewpoints inade decision-making so difficult that the

Court was compelled to embark on the practice of summarily reversing convictions for the dissemination of materials that at least five members of the Court, applying their separate tests, found to be protected by the First Amendment. ${ }^{54}$

Resort to such summary disposition-while preferable to no decision at all-deunonstrates the futility of the Court's efforts to establish a consistent position on the obscenity issue during that period. While the "contemporary cominunity standards" test recently enunciated in Miller v. California ${ }^{55}$ may entail severe problems in its application, as an "Opinion of the Court" it has at least established an ascertamable position of the Court as an imstitution on the obscenity issue. As such, any future developments in that area of the law must resort to that opinion as a point of departure.

50. E.g., Ginzburg v. United States, 383 U.S. 463, $481-82$ (1966) (Black, J., dissenting); Roth v. United States, 354 U.S. 476, 512-14 (1957) (Douglas, J., dissenting).

51. E.g., Ginzburg v. United States, 383 U.S. 463, 470-71 (1966); Jacobellis v. Ohio, 378 U.S. 184, 195 (1964). Justice Brennan has since refined his position, which he articulated in his recent dissent in Paris Adult Theatre I v. Slaton, 413 U.S. 49, 73, 113 (Brennan, J., dissenting):

I would hold, therefore, that at least in the absence of distribution to juveniles or obtrusive exposure to unconsenting adults, the First and Fourteenth Amendnents prohibit the State and Federal Governnents from attempting wholly to suppress sexually oriented materials on the basis of their allegedly "obscene" contents.

52. E.g., Jacobellis v. Ohio, 378 U.S. 184, 204 (Harlan, J., dissenting).

53. As Justice Harlan noted, the Court's efforts to define obscenity have "produced a variety of views among the members of the Court unnatched in any other course of constitutional adjudication." Interstate Circuit, Inc. v. Dallas, 390 U.S. 676, 70405 (1968) (Harlan, J., concurring and dissenting).

See also the discussion of the relevant precedents in Miller v. California, 413 U.S. 15, 19-25 (1973) (Burger, C.J.), and Paris Adult Theatre I v. Slaton, 413 U.S. 49, $79-93$ (1973) (Brennan, J., dissenting).

54. Miller v. California, 413 U.S. 15, 22 n.3 (1973). The process began with Redrup v. New York, 386 U.S. 767 (1967).

55. 413 U.S. 15 (1973). 


\section{Confusion in the Lower Courts}

Because plurality decisions lack a single ratio decidendi, those who must interpret Supreme Court decisions, if they are not to limit the reading of the decision to a mere judgment, must-and often do"guess" at the Court's reaction when faced with a somewhat similar case. ${ }^{50}$ Of course, this practice is not unique to no-clear-majority decisions: even "clear majority" opinions often contain ambiguitieseither through madvertence, or because of a deliberate fudging or vagueness built into the opinion to secure the support of a wavering colleague. Such ambiguity may also be generated by sub silentio gnawings at the theoretical underpinnings of an earlier case. A lower court may even indulge in speculation concerning the position new members of the Court will take on seemingly settled issues. ${ }^{57}$ In one notable recent decision, ${ }^{58}$ for example, the Arizona Supreme Court rejected the due process prerequisites to prejudgment repossession set forth in Fuentes $v$. Shevin ${ }^{59}$ because that case was the result of a 4 to 3 decision; the Arizona court conjectured that the Supreme Court, as brought to full

56. The predicament of the lower courts in this situation is well illustrated by the following language extracted from the recent Third Circuit opinion in Gordon v. Random House, Inc., 486 F.2d 1356 (1973), where the Court rejected as binding precedent Justice Brennan's plurality opinion in Rosenbloom v. Metromedia, Inc., 403 U.S. 29 (1971), see note 109 infra (which had extended the "knowing or reckless falsehood" constitutional libel standard of New York Times Co. v. Sullivan, 376 U.S. 254 (1964), to matters of general public concern):

Confronted with the foregoing diverse expressions, we are unable to share the certainty of the district court $\mathrm{m}$ accepting the Rosenbloom plurality as the law of this case. Justice Holines" definition of law comes to mind: "The prophecies of what the courts will do in fact, and nothing more pretentious, are what I mean by the law." 486 F.2d at 1360 (footnotes ounitted).

Another manifestation of this type of lower court uncertainty (albeit caused by the separate views expressed by the Justices in support of a per curiam, rather than a plurality, opinion) is the wrestling by state courts with the question of whether Furman v. Georgia, 408 U.S. 238 (1972), forbids all executions. See, e.g., the several opinions in State v. Waddell, 282 N.C. 431, 194 S.E.2d 19 (1973), and Bartholomey v. State, 267 Md. 175, 297 A.2d 696 (1972).

57. Perhaps the most famous example of this by a lower federal court is Judge Parker's decision in Barnette v. West Virginia State Bd. of Educ., 47 F. Supp. 251 (S.D.W. Va. 1942), aff'd, 319 U.S. 624 (1943), correctly predicting the overruling of Minersville School Dist. v. Gobitis, 310 U.S. 586 (1940). See also Gordon v. Random House, Inc., 486 F.2d 1356, 1360 (3d Cir. 1973), discussed supra note 56, where the court noted:

Confronted with such divergence on the Supreme Court level, we suggest that the accuracy of our "propliecies" will depend upon the yet unarticulated First Amendment philosophies of Justices Powell and Rehnquist.

58. Roofing Wholesale Co. v. Palmer, 108 Ariz. 508, 502 P.2d 1327 (1972) (en banc), criticized in 86 HARV. L. REv. 1307 (1973). See also State ex rel, Williams v. Berrey, 492 S.W.2d 731, 736 (Mo. 1973) (dissenting opinion).

59. 407 U.S. 67 (1972). 
strength since Fuentes, would now decide that case differently, and thus rejected the Fuentes holding as binding precedent. ${ }^{60}$

On the other hand, soine no-clear-majority opinions present no real problems to lower courts because the concurring ineinbers have been able to agree (either overtly ${ }^{61}$ or covertly ${ }^{02}$ ) on a "highest" common denominator for their decision. Thus, the 1972 case of Peters $v$. Kiff, ${ }^{63}$ upholding a white petitioner's challenge to his conviction on the ground that blacks were systematically excluded from the grand jury that indicted him, should not confuse lower courts simply because three members of the Court reached that result on constitutional grounds, ${ }^{64}$ while three others relied on statutory authority ${ }^{65}$ in doing so. ${ }^{60}$ The "highest" coininon denominator of that decision is that systematic exclusion of a racial group froin a grand jury is grounds for the reversal of a conviction based upon an indictnent by such a segregated grand jury. A lower court need not grasp the precise theoretical underpinnings of the Peters holding in order to be able to properly apply its rule.

Frequently, however, there is no discernible unifying thread in the several opinions, and the examples of the problems occasioned by such ambivalence are legion. In the areas of obscenity ${ }^{87}$ and retroactivity, ${ }^{68}$

60. 108 Ariz. at 510-11, 502 P.2d at 1329-30.

61. See text accompanying notes 108-09 infra.

62. In Glidden Co. v. Zdanok, 370 U.S. 530 (1962), for example, the opinions of Justice Harlan and Justice Clark, taken together, create a majority for the following statements: (1) there had been no waiver of the right to cliallenge the jurisdiction of judges of the Court of Claims sitting in article III courts; (2) for some reason, judges of the Courts of Claims and of Customs and Patent Appeals are article III judges; (3) after some point in time (1958) those judges were article III judges. Although not formally agreed upon, it is clear that Glidden stands for at least the above propositions.

63. 407 U.S. 493 (1972).

64. Justice Marsball, joined by Justices Douglas and Stewart, was of the view that cousiderations of due process alone were sufficient to justify reversal. Id. at 505 .

65. Justice White, joined by Justices Brennan and Powell, preferred to base reversal on the statutory authority of 18 U.S.C. $\$ 243$ (1970), which forbids the exclusion of otherwise qualified citizens from jury service on the basis of race, color, or previous condition of servitude. 407 U.S. at 505-07.

66. Most of the cases which cite Peters do so for the simple proposition noted in the text. E.g., United States ex rel. Davis v. Henderson, 474 F.2d 1098, 1101 (5th Cir. 1973); Mosley v. Smith, 470 F.2d 1320, 1321 (5th Cir. 1973); Mayfield v. Steed, 345 F. Supp. 806 (E.D. Ark. 1973), aff'd, 473 F.2d 691 (8th Cir. 1973). Others specifically note that Peters was a plurality decision. E.g., United States v. Olson, 473 F.2d 686, 688 (8th Cir. 1973).

67. The problem of deciding obscenity cases in the lower courts is illustrated by the difficulty various courts had in determining whether or not a motion picture entitled "I AM CURIOUS (YELLOW)" was obsceue. The Court of Appeals for the Second Circuit decided that its importation could not be barred. United States v. A Motion Picture, 404 F.2d 196 (2d Cir. 1968). And a state court in New Jersey held that 
discussed above, as well as in the context of the constitutionality of libel laws, ${ }^{\circ 9}$ for example, conflicting and often confused decisions in the lower courts were the product of the Court's inability to give stability to the development of constitutional law. ${ }^{70} \mathrm{~A}$ striking example of the confusion occasioned by such plurality decisions is presented by the efforts of the Maryland courts, and subsequently by a United States District Court and the Court of Appeals for the Fourth Circuit, to apply the "holding" in United States $v$. Jorn. ${ }^{71}$ Jorn involved the application of the fifth amendment double jeopardy protection to a sua sponte judicial declaration of mistrial. Justice Harlan, writing for himself and three other members of the Court, expressed the opinion that when a judge has abused his discretion in aborting a trial, the defendant may imvoke double jeopardy if he is brought to trial again

it was not without redeeming social value. Lordi v. UA New Jersey Theatres, Inc., 108 N.J. Super. 19, 259 A.2d 734 (1969). The highest court of Maryland, however, held that it was obsceue. Wagonheim v. Maryland State Bd. of Censors, 255 Md. 297, 258 A.2d 240 (1969). The Supreme Court did not clarify matters when it affirmed the Maryland decision by an equally divided court. Grove Press, Inc. v. Maryland State Bd. of Censors, 401 U.S. 480 (1971). In Karalexis v. Byrne, 306 F. Supp. 1363 (D. Mass. 1969), rev'd, 401 U.S. 216 (1971), the obscemity of "I AM CURIOUS (YELLOW)" was not at issue, the case going off on the jurisdiction of a federal court to enjoin a state criminal proceeding. Despite the division of opinion as to the constitutionality of forbidding the exhibition of "I AM CURIOUS (YELLOW)" there were many state prosecutions. An appendix to the Jurisdictional Statement filed in the Supreme Court in the Maryland case listed twenty-three cases in thirteen different states involving the film.

68. For a compilation of the diversity of opinion on the retroactivity of $O^{\prime} \mathrm{Calla}$ han, see Gosa v. Mayden, 413 U.S. 665, 671-72 n.5 (1973) (Blackmun, J.).

69. See Rosenbloom v. Metromedia, Inc., 402 U.S. 29 (1971), discussed at note 56 supra.

70. It is for this reason that Justice Schaefer of the Illinois Supreme Court has suggested that better "predictability" is achieved by the issuance of opinions seriatim. Schaefer, Precedent and Policy, 34 U. CHI. L. REv. 3, 9 (1966). Greater predictability would probably result from sucl a practice, but only in the sense that the holding extracted from the several opinions will be quite narrow, thereby aiding the determination of whether the case at bar is controlled by precedent. Whatever may be the virtues of such a system in a common law court (cf. Keeton, Creative Continuity in the Law of Torts, 75 HARV. L. REv. 463, 488-89 (1962))-and the English seein to have survived very well under such a system-the uncertainty inherent in that process is intolerable in constitutional decision-1naking; the Supreme Court's primary responsibility is to provide guidance for those who must apply the organic law to those inyriad fact patterns involving fundamental rights which have not-and may never-come to the attention of the Court.

It should be noted that the Supreme Court originally issued its opinions seriatim, a practice which ended with John Marshall and the assumption by the Court of the full range of its constitutioual powers. ZoBell, supra note 3, at 192-93. An occasional lainent for that earlier practice can be found. E.g., Graves v. New York ex rel. O'Keefe, 306 U.S. 466, 487 (1939) (Frankfurter, J., concurring).

71. 400 U.S. 470 (1971). 
for the same offense. ${ }^{2}$ Justice Stewart, jomed by two other members of the Court, disagreed with that conclusion on the inerits, arguing that the defendant must further establish that the abuse had prejudiced him. ${ }^{73}$ Justices Black and Brennan believed that the Supreme Court lacked jurisdiction to hear the case

.. . because the action of the trial judge amounted to an acquittal of appellee and therefore there was no discretion left to the trial judge to put appellee again in jeopardy. However, in view of a decision by a majority of the Court to reach the merits they joined the judgment of the Court. ${ }^{74}$

A year later the Maryland Court of Special Appeals was faced with the same problem presented to the Supreme Court in Jorn. ${ }^{75}$ That court, after noticing that Jorn was the product of a divided Court, ${ }^{70}$ ruled that

[t]he opinion of the plurahity of four Justices is no more controlling in this State than is the dissenting opinion of the three Justices. Therefore, we may look at the Harlan opinion and the Stewart opinion only in the frame of reference of their persuasiveness. ${ }^{77}$

After analyzing the several opinions in Jorn, the Maryland Court concluded that Justice Stewart's opinion in Jorn represented the better application of the earlier cases and, therefore, demed relief to appellants. ${ }^{78}$ One of the appellants in the Maryland case then sought federal habeas corpus relief. The United States District Court declined to pass on the propriety of the state court's views as to the binding nature of Supreme Court plurality opinions because the court felt itself bound by Fourtl Circuit precedents, which liad adopted Justice Harlan's plurality position. ${ }^{79}$ On this basis, the court granted the writ-only to be re-

72. Id. at 486-87.

73. Id. at 492 .

74. Id. at 488.

75. Baker v. State, 15 Md. App. 73, 289 A.2d 348 (1972).

76. In one sense it could be said that there was a "majority" position in Jorn, for the concurring opinion of Justices Black and Brennan states that if one assumes, as the other seven justices did, that the Supreme Court had jurisdiction to decide the issue, then Justices Black and Brennan concur in the plurality's holding that a trial judge's abuse of his discretion to declare a mistrial causes the double jeopardy guarantee to attach. 400 U.S. at 488. See also Whitfield v. Warden, 355 F. Supp. 972, 976-77 (D. Md. 1973).

77. 15 Md. App. at 82, 289 A.2d at 354. See also the opinions in Holmes v. Burr, 486 F.2d 55 (9th Cir. 1973).

78. A dissenting opinion agreed that the Maryland court was not bound by a plurality opinion but, on analysis, found Justice Harlan's position more convincing. 15 Md. App. at 110, 289 A.2d 369.

79. Whitfield v. Warden, 355 F. Supp. 972 (D. Md. 1972). 
versed by the Fourth Circuit, which apparently viewed the Jorn opinion in yet another light. ${ }^{80}$

Quite obviously, much of the litigation involved in this case could have been obviated by a inajority opinion in Jorn. The Court's failure to delineate clearly the scope of its holding necessitated, in the case of this one criminal defendant, the preparation of three elaborate opinions by three separate courts to resolve an issue which need never have arisen. In light of the currently expressed concern with the problem of backlog in the lower courts' calendars, ${ }^{81}$ the Court might do well to consider such consequences of the failure to reach a clear majority when it sits down to structure its decisions.

\section{STRATEgic CONSIDERATIONS}

Plurality decisions involve multiple opinions, usually by three, and often more, members of the Court. Sucli opinions, because they need not engage in the minor concessions sometimes necessary to secure a majority on the priniary issue, are freer to engage in extended argument on limited points; they thus serve to isolate vital issues and bring thein to the attention of the public and the profession. As Chief Justice Hughes wrote:

A dissent in a court of last resort is an appeal to the brooding spirit of the law, to the intelligence of a future day, when a later decision may possibly correct the error into which the dissenting judge beheves the court to have been betrayed. ${ }^{82}$

A strategically placed concurring opmion-perhaps completing the majority necessary to reacli a particular judgment-can thus occasionally illuminate issues which might otherwise be relegated to the obscurity of a footnote. Yet, frequent indulgence in the luxury of expressing individual views can undermine the very special value of concurring and dissenting opinions. Used too often, the separate opinion can assume the cliaracter of the repeatedly uttered cry of "wolf," and cease to be viewed as a signal that here is an issue worthy of attention. ${ }^{83}$

80. Whitfield v. Warden, 489 F.2d 1119, 1121 (4th Cir. 1973) (where the court apparently treated the decision in Jorn as though it had been an opinion of the Court).

81. See, e.g., Chief Justice Burger's cominents in Burger, The State of the Federal Judiciary-1972, 58 A.B.A.J. 1049 (1972).

82. C. Hughes, The Supreme Court of the United States 68 (1928). There are many examples of such dissents. See generally P. JACkSON, DISSENT IN THE SuPREME COURT (1969).

83. Or, as Chief Justice Stone once wrote to Karl Llewellyn: "You know, if I should write in every case where I do not agree with some of the views expressed in 
It would sometimes appear, however, that a justice's refusal to join a plurality opinion - a refusal which emasculates the authority of that opinion in those cases wherein a majority position is thereby precluded-is motivated by strategic, rather than purely legal, considerations. Underlying the refusal may be the hope that the particular issue, if bypassed, will not be resurrected in the future. Alternatively, the reluctant justice may prefer to reserve binding judicial resolution until Congress acts on the matter and resolves the issue with specific legislation, or until the views expressed in separate opinions have generated sufficient public and professional debate on the issue for the Court to be able to gauge the general reaction to a contemplated change in the law.

Frontiero v. Richardson ${ }^{84}$ illustrates this latter tactic. In that case four menibers of the Court, led by Justice Brennan, were willing to hold that classification on the basis of sex falls into the "inherently suspect" category; ${ }^{85}$ three justices jomed Justice Powell in concluding that the statutory classification in question should be struck down as "unsupportable," emphasizing that it was "unnecessary" to decide whether all sexual classifications are inherently suspect. ${ }^{86}$ Justice Stewart noted separately that the challenged regulation inust fall because it worked an "invidious" discrimination. ${ }^{87}$

As delaying tactics, both of the latter opinions make sense, for Frontiero had provided the Court with an invitation to enter a highly sensitive area. Acceptance of that invitation was complicated by the pendency of a proposed amendment to the Constitution dealing with the legitimacy of classifications based on sex; the amendinent had been ratified by approximately thirty states, but the ratification movement had stalled. ${ }^{88}$ If the Equal Rights Amendinent is finally adopted, any position assumed by the Court on this touchy issue will be rendered moot. By foregoing a direct resolution of the issue, the Court avoided the critical exposure which may have resulted from adopting the Bren-

the opinions you and all my other friends would stop reading them." Quoted in W. MURPHY, THE ELEMENTS OF JUdicial STRATEgY 62 (1964).

84. 411 U.S. 677 (1973).

85. Id. at 682 .

86. Id. at 691-92.

87. Id. at 691. Justice Rehnquist dissented, id. Frontiero has apparently already led to confusion in lower courts. See, e.g., Ballard v. Laird, 360 F. Supp. 643 (S.D. Cal. 1973).

88. Similar considerations to those prevailing while Frontiero was being decided may have also contributed to the plurakity result in Oregon v. Mitchell, 400 U.S. 112 (1970), which was dccided just prior to the necessary ratification of the 26th Amendment. 
nan opinion as its own. If the amendment is not enacted, the Court must eventually squarely face the problem of sexual classification, but, in the meantime, it will have had the advantage of the public and professional commentary flushed out by Justice Brennan's opinion.

\section{Causes of the Plurality Trend}

As indicated earlier in this Article, ${ }^{89}$ the imcidence of plurality opinions has increased markedly over the life of the Court. Although the last two terms have produced nothing approaching the fifteen plurality opinions which occurred in the 1970 Term, the eleven plurality opinions which they did produce clearly indicate that the phenomenon is likely to recur with substantial regularity unless affirmative measures are taken to minimize its occurrence. Moreover, to the extent that an ideological split exists within the current Court, it can be expected that that factor will further tend to generate polarized decisions. ${ }^{90}$

The composition of the present Court aside, several of its institutional characteristics may be related to the long-term trend towards plurality opinions. In the first place, students of the Court in recent years have suggested that its current workload is too heavy for it fully to accoinplish its inission. ${ }^{91}$ Time expended in reducing an everexpanding docket to manageable size reduces the time available for formulating opinions; in particular, the process of resolving differences of opinion among the members of the Court would often seem to require a good deal of collegial criticism, followed by reflection and redrafting of opinions to reflect those criticisms. That this "maturing of collective thought" ${ }^{22}$ is time-consuming cannot be doubted, although doubts have been expressed that real common ground is often reached.93 A glance

89. See text accompanying notes 2-6 supra.

90. See generally The Supreme Court, 1971 Term, 86 HARv. L. REv. 1, 297-301 (1972).

91. The latest, and probably most thorough, study is that of the FEDERAL JUDICIAL Center, Report of the Study Group on the Caseload of the Supreme Court (1972). The view that the Supreme Court is overworked is hardly a unanimous one. See, e.g., former Chief Justice Warren's remarks in 59 A.B.A.J. 724 (1973), and those of Justice Douglas in The Supreme Court and Its Caseload, 45 CoRnell L.Q. 401 (1960).

92. Hart, Foreword: The Time Chart of the Justices, 73 HARv. L. REv. 84, 100 (1959).

93. Compare id. and Griswold, Foreword: Of Time and Attitudes-Professor Hart and Judge Arnold, 74 HARv. L. REv. 81 (1960), with Arnold, Professor Hart's Theology, 73 HARV. L. REV. 1298 (1960), and Lewin, Helping the Court with Its Work, The New Republic, Mar. 3, 1973, at 15-19.

A fair amount of historical evidence suggests that "individual votes and even decisions have undergone change during the process of writing and circulating draft opin- 
at some of the Court's recent decisions suggests, however, that the most elementary of "collective thought"-at least if undertaken with good will-could have transformed some no-clear-majority decisions into firm holdings.

The differences of opinion among the factions supporting the decisions in United States v. Midwest Video Corp. ${ }^{04}$ or Glidden, ${ }^{05}$ for example, hardly appear so great as to have precluded mutual reconciliation. In Midwest Video, the disagreennent between Justice Brennan's four-man opinion and the Chief Justice's separate statement in support of the judgment apparently centered on exactly how "clear" it was that certain cable television regulations promulgated by the Federal Communications Commission were within that body's rulemaking authority. ${ }^{06}$ Since Congress could, if it were so disposed, easily alter the Commission's mandate, it is difficult to explain why the justices could not have agreed on an opinion of the Court holding narrowly that the Commission's authority had not been exceeded in that case. In Glidden, the only expressed difference between the opinions of Justices Harlan and Clark was over the question of exactly when the Courts of Claims and of Customs and Patent Appeals became "Article III Courts." precise answer to that question was not necessary for the resolution of the case, there appeared no justification for a divided majority. ${ }^{98}$

Of course, the game of reconciliation might not be worth the candle; Justice Brennan almost surely could have obtamed a majority in Frontiero $v$. Richardson" if he had been willing to strike the "inherently suspect" language in his opinion. He was hardly likely to do so, however, if the opinion as written reflects deeply held beliefs. The point is, of course, that accommodation of different views, while not always possible, can with some effort frequently be effected. ${ }^{100}$

ions." Griswold, supra, at 93. Superb examples can be found in the Second Circuit's "memorandum" practice under Learned Hand. See M. Schick, LeArned HAND's CourT passim (1970). See also W. MuRPHY, supra note 83, at 37-90.

94. 406 U.S. 649 (1972).

95. 370 U.S. 530 (1962).

96. 406 U.S. at $675-76$.

97. 370 U.S. at $584,585-89$.

98. However, simce Glidden was one of those rare instances in which it was the judgment, and not the underlymg opinions, which was of significaut impact, no real harm was occasioned by the failure to coalesce on a majority opinion. See text accompanying notes 12-13 supra.

99. See text accoinpanying notes 84-87 supra.

100. See generally the discussion of Camara v. Municipal Court, 387 U.S. 523 (1967), in P. JACKsON, supra note 82, at 16.

For an examination of the "bargaining" strategies possible in this situation see W. MurPHY, supra note 83 , at 56-72. Murphy notes that "[w] 
It is not clear to what extent the pressures of work hinder this process. ${ }^{101}$ Despite Justice Douglas' claim that the Court is "vastly underworked,"102 it is probable that a reduced caseload would aid the Court in its effort to iron out internal controversy. ${ }^{103}$

And yet the lack of sufficient time, by itself, is hardly an adequate answer. Did the circuit-riding justices of the late 19th century have more time and energy to spend in intensive collegial effort than the present Court? ${ }^{104}$ Might more time simply result in inore energy available for drafting of separate statements? ${ }^{105}$ And it is by no means clear that extensive efforts at reconciliation will in all cases lead to clearer opinions, with a single voice speaking for a majority of the Court. ${ }^{108}$ It is unlikely, for instance, that even protracted efforts to

vided any Justice can wield great influence," and quotes a memorandum from Justice Gray to Justice Miller:

After a careful reading of your opinion in Shotwell $v$. Moore, I am very sorry to be coinpelled to say that the first part of it (especially in the passage which I have inarked in the margin) is so contrary to my convictions, that I fear, unless it can be a good deal tempered, I shall have to deliver a separate opinion on the lines of the enclosed memorandum.

I am particularly troubled about this, because, if my scruples are not removed, and Justices Field, Bradley and Lamar adhere to their dissent, your opinion will represent only four judges, half of those who took part in the case.

Not surprisingly, Justice Miller modified his opinion. Id. at 57-58.

101. There are occasional cases in which the urgent necessity for a hasty disposition of the controversy before the Court may have led to multiple opinions. See, e.g., New York Tinies Co. v. United States, 403 U.S. 713 (1971). As Justice Harlan noted in the Times case, "I consider that the Court has been almost irresponsibly feverish in dealing with these cases." Id. at 753 (Harlan, J., dissenting). Such cases appear rather infrequently, however.

102. Tidewater Oil Co. v. United States, 409 U.S. 151, 178 (1972) (Douglas, J., dissenting).

103. A relatively simple alteration in the Court's procedures would eliminate the division of the Court's labors into "Terms," thus alleviating the pressure to "clear the docket" at the conclusion of each Term and eliminating sone of the last minute divisions of the Court which regularly occur at that time. Cf. Federaz Judicial Center REPORT, supra note 91 , at $40-41$.

104. Cf. H. Hart \& H. Wechsler, The Federal Courts and the Federal SysTEM 36-40 (P. Bator ed. 1973).

105. See, e.g., P. Freund, ON UNDERstanding the Supreme Court 76 (1950), discussing Justice Brandeis: "Not infrequently the preparation of a dissenting opinion was forgone because the demands of other items of work prevented an adequate treatment ...."

106. The Learned Hand court gives further evidence of how collective effort can prove futile at times. Despite that court's "memorandum" approach, concurring or dissenting opinions were filed in over $15 \%$ of the cases-a number that seems high given the relatively simple nature of so much of the work of an intermediate appellate court. M. Schick, supra note 93, at 313. The historian of that court has suggested that the memorandum method may have contributed to the number of separate opinions. $I d$, at 318 . 
achieve reconciliation would have persuaded a majority to join Justice Rehnquist's three-man-opinion in First National City Bank v. Banco Nacional de Cubas, ${ }^{107}$ which held the "act of state" doctrine inapplicable in those situations where the Executive Branch had stated that non-application of that doctrine would not hinder the working of American foreign policy. Justices Douglas and Powell, for example, who completed the majority needed to reverse the decision of the district court, both expressed unease and disagreement with that portion of Justice Rehnquist's opinion. ${ }^{108}$ It seeins equally clear that no amount of collegial negotiation could have enticed Justice Black into modifying his absolutist first ainendment views sufficiently to have joined Justice Brennan's more temporizing opinion in Rosenbloom v. Metromedia, Inc. ${ }^{100}$

Another major factor contributing to the high number of no-clearmajority opinions is the Court's prominent role in creating major social change. As the "expected" final arbiter of constitutional disputes, the Court must rule upon a number of perplexing and volatile social problems that the legislative and executive branclies have been unable or unwilling to resolve. In passing upon such explosive and far-reaching issues as the constitutionality of the death penalty, for instance, ${ }^{111}$ or the legality of state grants to religious educational imstitutions, ${ }^{112}$ it is understandable for a justice to take pains to assure that history accurately notes his view. ${ }^{113}$ Narcissism aside, agreement on such issues

107. 406 U.S. 759 (1972).

108. Justice Douglas concurred in the result not because of the State Department's indication that no adverse foreign policy consequence would ensue, but solely on the ground that, since the Cuban National Bank had sought the United States court's protection in the first instance, "'fair dealing' requires recognition of any counterclain or setoff that eliminates or reduces that claim." Id. at 772 (Douglas, J., concurring). Justice Powell based his concurrence upon a much narrower interpretation of the "act of state doctrine" than that reflected in Justice Rehnquist's opinion. Id. at 773-76 (Powell, J., concurring).

109. 403 U.S. 29, 57 (1971) (Black, J., concurring). Whereas the Brennan opinion in Rosenbloom still allowed room for hibel judgments against the news media if the plaintiff could meet the knowing-or-reckless falsehood standard of New York Times Co. v. Sullivan, 376 U.S. 254 (1964), Justice Black insisted that the first amendment barred such judgments "even when statements are broadcast with knowledge they are false." 403 U.S. at 57.

110. Monaghan, supra note 7 , at 1368.

111. In Furman v. Georgia, 408 U.S. 238 (1972), all nine justices wrote separate opinions.

112. In Lemon v. Kurtzman I, 403 U.S. 602 (1971), striking down Pennsylvania and Rhode Island statutes under which the state paid a portion of the salaries of nonpublic schoolteachers, five justices felt it necessary to file either opinions or separate statements. See also Tilton v. Richardson, 403 U.S. 672 (1971) (plurality opinion with four separate opimions filed); Lemon v. Kurtzman II, 411 U.S. 192 (1973) (also resulting in a plurality opinion).

113. Indeed, Jefferson thought each justice should be required to express his own 
is likely to be harder to reach; the more a decision turns on a question of basic political beliefs rather than on the construction of precedent, for instance, the more likely it is that each justice will insist on insuring that his view is heard. It is not surprising, therefore, that the four justices who believed classification by sex to be inherently suspect were unwilling to join the less expansive views of their brethren in Frontiero v. Richardson; ${ }^{114}$ or that all nine justices expressed their views on the death penalty issue in Furman v. Georgia, ${ }^{115}$ or, to go back much further, that the members of the Taney Court dehivered nine separate opinions in the Dred Scott case. ${ }^{118}$ The problem is exacerbated today by a shift in the ideological focus of the Court which has accompanied the appointments in the last four years of as many new justices; ${ }^{117}$ it is surely no coincidence that those Terms have witnessed the greatest number of no-clear-majority decisions in the history of the Court.

\section{Alternatives to the Plurality Opinion}

Given the institutional, ideological, and personal factors which tend to frustrate the achievement of consensus within the Court, the plurality opinion may continue to hinder the orderly development of constitutional and other federal law for years to come. Only good will and strong leadership ${ }^{118}$ can solve the problem. As the school desegregation, ${ }^{110}$ reapportionment, ${ }^{120}$ and abortion cases ${ }^{121}$ illustrate, when the Court bends its will to the task, it is possible, even with the most sensitive of issues, to subordimate individual differences enough to achieve, if not unanimity, at least a forceful voice speaking for the Court as an institution. After all, the nation is not overly interested in the views of any individual justice; it is, lowever, deeply concerned about the views of the Supreme Court as an institution. Still, all the good will and leadership in the world will not make all conflicting opinions disappear. An

position in each case before him. McWhinney, Judicial Concurrences and Dissents: A Comparative View of Opinion-writing in Final Appellate Tribunals, 31 CaN. B. REv. $595,609-10$ (1953).

114. 411 U.S. 677 (1973). See text accompanying notes $84-87$ supra.

115. 408 U.S. 238 (1972).

116. Dred Scott v. Sandford, 60 U.S. (19 How.) 393 (1857). One commentator has noticed a correlation between the rise in separate opinions and a shift in the Court's emphasis from property rights to human rights. McWhinney, supra note 113, at 61314.

117. See note 90 supra and accompanying text.

118. For a view as to the effect of leadership on the practice of issuing separate opinions, see McWhinney, supra note 113, at 617-19.

119. See text accompanying notes 16-20 supra.

120. E.g., Baker v. Carr, 369 U.S. 186 (1972).

121. Roe v. Wade, 410 U.S. 113 (1973); Doe v. Bolton, 410 U.S. 179 (1973). 
activist Court with strong-willed members will surely find itself faced at times with an irreconcilable difference of opinion among those desiring the same result.

It is in this type of situation that the Court can, for the guidance of those who must wrestle with the multiplicity of opinions generated in the "plurality" cases, employ a procedure which it has occasionally utilized in the past, but which has never really become a part of the Court's arsenal. In many cases it should be possible for the Justices who comprise the prevailing side to adopt a brief, perhaps per curiam, statement of the "highest common denominator" of the several individual views on that side. ${ }^{122}$ Obviously, such a procedure fails to realize the coinplete potential of a fully articulated opinion "of the Court." In those cases where it lias been used, for example, the reasoning underlying the judginent has been unspectacular. ${ }^{123}$ Yet the per curiam technique, we believe, has more potential than it has yet realized;:124 with some effort, the Court's express basis of decision can serve as precedent: formal overruling would then be necessary to turn the case upside down.

In the Fanny Hill case, ${ }^{125}$ for instance, the Court could have issued a brief statement to the effect that if a person can be convicted at all for distributing obscene literature, the prosecution must at least show that the material is "utterly without redeeming social value," a statement which in fact reflected the views of three members of the plurality. ${ }^{120}$ Justices Black and Douglas, whose concurrence in the result was premised on an absolutist reading of the free speech clause, should have been willing to concede that that was the minimal showing required of the prosecution. If the Fanny Hill case had followed that route, the opinion of the Court last term in Miller $v$. California, ${ }^{127}$ would have been forced to acknowledge its departure from precedent, instead of asserting, as the Chief Justice did, that the "concept" of "utterly without redeeming social value," enunciated in Fanny Hill, "has never

122. Two examples of the use of this technique are Furman v. Georgia, 408 U.S. 238 (1972), and New York Times Co. v. United States, 403 U.S. 213 (1971).

123. The per curiam statement in Furman v. Georgia, 408 U.S. 238 (1972), for instance, has done little to settle the continuing doubts as to the permissible standards for the imposition of capital punishnient. See note 56 supra. See also Redrup v. New York, 386 U.S. 767 (1967).

124. The resort to a per curiain opimion may, on occasion, result front the fact that separate parts of an opinion may have been written by different iudges. See, e.g., Nixon v. Sirica, 487 F.2d 700 (D.C. Cir. 1973).

125. A Book Named "John Cleland's Memoirs of a Woman of Pleasure" v. Attorney General, 383 U.S. 413 (1966).

126. Id. at 418 (per Brennan, J.).

127. 413 U.S. 15 (1973). See note 26 supra and accompanying text. 
commanded the adherence of more than three Justices at one time."128

The per curiam technique, of course, is not a complete panacea. One problem is that the split of opinion in some cases is so great that no common ground can be found. National Mutual Insurance Co. $v$. Tidewater Transfer Co. ${ }^{128}$ provides just such an example. The question before the Court in that case concerned the constitutionality of the statute which conferred jurisdiction for diversity purposes based on citizenship in the District of Columbia. Three members of the Court thought the statute could not be sustained on any ground; ${ }^{130}$ three thought Congress could so legislate under article I, but not under article III; ${ }^{131}$ and three thought Congress could so legislate under article III, but not under article I. ${ }^{132}$ Thus, a majority of the Court concluded that the legislation could not be sustained under article I while a differently composed majority also concluded that it could not be sustained under article III; but the upshot of the case was to hold the statute constitutional. It is most unlikely, therefore, that any common ground could have been achieved in the Tidewater case. More fundamentally, a latent danger inherent in the use of the per curiain technique is that it could easily become a wonderfully attractive device for postponing difficult decisions. ${ }^{133}$ Thus, although the Court's per curiam opinion in Furman v. Georgia ${ }^{134}$ held that capital punishnent was unconstitutional as applied under the circumstances of that case, the opinion put off to another day the problem of precisely defining the circunistances whicls would immunize inposition of the death penalty from constitutional attack. ${ }^{135}$

In those instances where even the per curiain technique proves unworkable, an alternative might be to separate the body of each opmion into discrete "sections" which reflect the view of the writer and those other members of the Court who join with him on each issue. A decision handed down at the end of the 1972 term, United States

128. Id. at 24-25. Having thus dismissed the "utterly without redeeming social value" standard, the Miller majority was then in a position to adopt a new standard without explicitly overruling a battery of prior obscenity decisions.

129. 337 U.S. 582 (1949). See generally Chicago Comment 107-08.

130. Id. at 626-55.

131. Id. at 581-604.

132. Id. at 604-26.

133. Cf. Ex Parte Quirin, 317 U.S. 1 (1942); Mason, Inter Arma Silent Leges: Chief Justice Stone's Views, 69 HaRv. L. Rev. 806, 813-31 (1956) (Professor Mason's description of the machinations in the case).

134. 408 U.S. 238 (1972).

135. See note 56 supra. 
v. Pennsylvania Industrial Chemical Corp. ${ }^{136}$ is a relatively simple example of this technique. That case involved a review of a criminal conviction for violation of the Rivers and Harbors Act of $1899^{137}$ by the deposit of wastes in the Monongahela River. Justice Brennan announced an opinion of the Court in which Justices Douglas, White and Marshall, a total of four justices, joined in toto. Part I of the opinion dealt with whether a section of the Rivers and Harbors Act was selfexecuting or whether it required resort to administrative procedures by the Army Corps of Engineers. Justice Brennan's opinion concluded that it was self-executing. On this segment of the opinion, the Chief Justice and Justices Stewart and Powell dissented, but Justices Blackmun and Rehnquist concurred, resulting in a majority and therefore a Court opinion deciding that issue. In Part II of Justice Brennan's opinion, he stated that the case must be remanded to the district court for a hearing on whether the defendants had been misled by the longstanding administrative construction by the Corps of Engineers that physical obstruction was necessary to constitute a violation. On the need for further hearing in the district court, the Chief Justice and Justices Stewart and Powell concurred, but Justices Blackmun and Rehnquist dissented. Again there was a majority, although made up of a different coahition. The end result is a relatively straightforward resolution of the issues.

A less happy result was achieved in Columbia Broadcasting System v. Democratic National Committee. ${ }^{138}$ That case involved the legality and constitutionality of the refusal of the Columbia Broadcasting Systein (CBS) to accept paid programs on public interest issues. The overall result was to uphold CBS's refusal to accept such programs, but the divisions of the Court in arriving at that conclusion almost require the use of a third generation computer to sort out the varying positions of the nine Justices participating. The Deinocratic National Committee and the Business Executives' Move for Vietuam Peace alleged that the refusal of their programs violated the "public interest" requirements of the Commumications Act and the first amendment. The chief author in the case was the Chief Justice. He divided his opinion into four parts, Parts I and II of which dealt respectively with the policy of the Act and the history of the "Fairness Doctrine." His opinion in these two Parts attracted the support of five other justices; another concurred in the result, and two dissented. Parts I and II, therefore, speak for

136. 411 U.S. 655 (1973).

137. 33 U.S.C. $\$ \S 401$ et seq. (1970).

138. 412 U.S. 94 (1973). 
the Court. ${ }^{139}$ Two justices only joined the Chief Justice in Part III, ${ }^{140}$ which held that there was insufficient government involveinent to bring the first amendment into play. Four justices did not reach the issue and two dissented. Although there was no majority, a three-two plurrality resulted on that issue. On Part IV, ${ }^{141}$ which held that neither the Communications Act nor the first amendment required the acceptance of such programs, the opinion attracted the support of four other justices, resulting in a majority. Justice Brennan, in dissent, ${ }^{142}$ asserted that that view was merely dicta with respect to the opinion of the two justices who had held that the first amendment was not involved by reason of the absence of governmental involvement, but nevertheless this Part was announced as an opinion of the Court. Justice Douglas joined in none of the opinions on the ground that CBS's first amendment rights gave it the absolute right to refuse such programs. ${ }^{143}$ Justice Stewart joined in Parts I, II, and III of the Chief Justice's opinion, but also concurred with Justice Douglas. Justices Brennan and Marshall dissented. ${ }^{144}$ In this case, the device of dividing the opinion into its constituent parts failed to avoid the confusion normally created by plurality opinions. The only result that clearly emerges is that CBS need not accept the programs of the Democratic National Committee or the Vietnam Peace group and, presumably, while the composition on the Court remains unchanged, other similar cases would be decided in the saine way. But the reason underlying the result is so divided that the matter will have to be readjudicated before it can serve as a foundation for further developments in communications law.

Although the division of cases into separate sections is not possible in some instances, and although the Court's separation of the various factors leading to its decision may necessitate the use of a "scorecard" to keep an accurate count of the votes on each issue, the device does make it easier for nembers of the court to isolate their disagreement with other members. Hopefully, in so doing, that very practice may facilitate the process of reconciliation.

\section{CoNCLUSION}

There may appear in what we have written above an implication that, on occasion, plurality opinions are the product of design rather

139. Id. at 101-14.

140. Id. at 114-21.

141. Id. at 121-32.

142. Id. at $170-204$.

143. Id. at $148-70$.

144. Id. at 170 . 
than the result of a failure in the efficient operation of the collegial system. If the Court has at times deliberately chosen this path, it would mdicate that some members of the Court must have decided that to promulgate such a cripple was the least of the evils among the options available. It is impossible for an outsider to pass judgment on such a choice. However, the least that can be said is that the evil inherent in decision by plurality is not a minor one, and that members of the Court should consider well before choosing a path which leads to such confusion both within and without the Court. 